\title{
PEMIKIRAN TEOLOGI FAZLUR RAHMAN
}

\author{
Muhammad Amin Saleh Al-Habsy \\ Fakultas Ushuluddin Universitas Darussalam Gontor \\ Muhammadaminrdm01@gmail.com
}

\begin{abstract}
Fazlur Rahman is a reformer in the Islamic world of the 20th century. His presence with a number of ideas, brought fresh air for the re-enlightenment of the Islamic world, which at that time was in a state of sluggishness. Rahman's involvement in the world of Islamic renewal does look very serious, which is supported by writing a number of books and articles that discuss various fundamental Islamic issues. This figure succeeded in formulating a systematic and comprehensive methodology whose main focus was Islamic law in addition to other aspects. With this method he inaugurated his reformation. Fazlur Rahman focused his discussion on the issue of God as a functional existence, the Koran as a source and moral value, and prophethood as concrete evidence of God's love, and humans as responsible creatures. Likewise, he raised the discussion of the universe to be processed, Satan as a test for humans, and the afterlife as a place of human responsibility. All of these themes are discussed in one discourse which to some extent really shows dynamics. So much according to Rahman that we can talk about theology if it is associated with ethics in the Qur'an. A perfect discussion will not be possible, unless we are willing to end up revealing the entire contents of the book itself. In this regard, And even that is not possible except in the form of reading the Koran itself, and letting the holy book speak for itself. Fazlur Rahman also likes to make such statements.
\end{abstract}

Keywords: Fazlur Rahman, theology, Pakistan, Al-Qur'an, thought. 


\section{Pendahuluan}

Pendidikan sebagai usaha memanusiakan manusia agar sadar akan kemanusiaannya memang satu hal yang harus menjadi perhatian. Pendidikan menempati posisi yang sangat menentukan dalam berbagai dimensi. Sebuah bangsa akan mengalami kemajuan ataupun kemunduran ditentukan sejauh mana laju dan dinamika pendidikan yang ada. Maka dari sini tidaklah berlebihan manakala mengatakan bahwa substansi sebuah pendidikan yang ideal dengan realitas adalah sebuah keniscayaan. Sebagai bagian dari pendidikan, pendidikan Islam bermuara pada tujuan pencapaian keseimbangan manusia dalam kehidupannya. Hal ini yang menjadi salah satu prinsip penting pendidikan Islam bahwa manusia harus mampu menyeimbangkan antara jasmani dan rohani, individu dan masyarakat, intelektual dan emosional serta dunia dan akhirat Untuk mencapai tujuan pendidikan Islam, para filsuf Muslim terdahulu telah memberikan sumbangan pemikirannya terhadap perkembangan pendidikan Islam, di antaranya ada Al-Qabisi dan Al-Ghazali, yang cenderung bersifat konservatif. Mereka memandang persoalan pendidikan melalui kacamata agama murni. Ilmu yang dipandang murni (sejati) hanyalah ilmu yang berkaitan dengan akhirat saja. Kemudian ada Ibnu Sina, Al-Farabi, Dan Ibnu Rusyd, yang cenderung memandang persoalan pendidikan dengan kacamata religiusrasional. Mereka berpendapat bahwa ilmu yang penting adalah ilmu yang mampu mengembangkan spiritual dan memuaskan intelektual. Selanjutnya ada Ibnu Khaldun, yang memandang persoalan pendidikan cenderung bersifat pragmatis instrumental, yang berpendapat bahwa ilmu yang di pandang penting adalah ilmu yang berkaitan dengan kebutuhan langsung manusia baik dunia maupun akhirat, serta beberapa filsuf muslim lainnya, dimana para tokoh tersebut telah memberikan pengaruh besar dalam khazanah pemikiran pendidikan Islam diera modern. Hal ini dibuktikan dengan munculnya para ilmuwan muslim diera modern dengan gagasan baru dalam dunia pendidikan Islam, salah satunya adalah Fazlur Rahman. Fazlur Rahman menekankan pentingnya etika yang dipetik dari Al-Qur'an untuk dijadikan landasan pengembangan pemikiran dan praktik pendidikan. Rahman juga berpartisipasi dalam menformat strategi, tujuan, metode dan kurikulum pendidikan Islam yang up to date. ${ }^{1}$

\section{Biografi}

Fazlur Rahman dilahirkan di anak benua Indo-Pakistan yang ketika itu belum terpecah menjadi negara Pakistan yang berdiri sendiri seperti sekarang. Ia lahir pada tahun 1919 dan dibesarkan dalam lingkungan mazhab Hanafi. Namun demikian Rahman memiliki pemikiran yang liberal yang tidak begitu saja terikat oleh sekat-sekat mazhab yang ada. Selain mengenyam pendidikan formal di Madrasah, ia juga mendapat pendidikan dari ayahnya sendiri yang seorang "kyai" di Madrasah tradisional Deoban yang cukup terkenal dan bergengsi di anak benua Indo-Pakistan tersebut. Setelah mendapat gelar Ph.D untuk yang kedua kalinya, Rahman tidak langsung pulang karena ketika itu persepsi masyarakat Pakistan tentang sarjana-sarjana yang mendapat pendidikan dari Barat dipandang menyimpang sehingga mereka belum bisa menerima kehadiran para

${ }^{1}$ Hadi Prayitno, "konsep pemikiran Fazlur Rahman tentang modernisasi pendidikan islam dan relevansinya terhadap pendidikan islam di Indonesia”, Jurnal Al Fikri, Vol 2 No 2 2019, hal. 31 
pemikir-pemikiran kritis alumni Barat. Karena itulah Rahman untuk sementara tetap tinggal di Inggris dan mengajar selama beberapa tahun di Durham University, kemudian ia juga mengajar di Institute of Islamic Studies, dan juga pernah mengajar di McGill University Kanada dan menjabat sebagai Associate Professor of Philosophy2

Pada pertengahan dasawarsa delapan puluhan kesehatan Fazlur Rahman mulai terganggu karena penyakit kencing manis dan jantung yang dideritanya. Bahkan ketika dokter pribadinya telah memberikan lampu kuning agar mengurangi kegiatannya, ia tetap memenuhi undangan pemerin-tah Republik Indonesia pada musim panas 1985. Di Indonesia, Fazlur Rahman tinggal selama 2 bulan, melihat keadaan Islam di negeri ini sambil beraudiensi, berdiskusi, dan memberi kuliah di beberapa tempat. Akhirnya, pada tanggal 26Juli 1988 ia wafat di Amerika Serikat dalam usia 69 tahun setelah beberapa lama sebelumnya ia dirawat di Rumah Sakit Chicago.3

\section{Pokok Pemikiran Fazlur Rahman}

Hakikat keberadaan Pakistan merupakan kehendak kaum Muslim untuk dapat hidup secara sepenuhnya di bawah bimbingan Islam. Walaupun simbol dan ideologi agama telah digunakan untuk memobilisasikan dan mempersatukan umat Islam India pada masa pergerakan kemerdekaan, tidak ada kejelasan pengertian atau konsensus tentang kandungan nyata ideologi itu dan aplikasinya dalam struktur, program, dan kebijakan negara. Akibatnya, setelah negara impian itu terwujud, kontroversi yang berkepanjangan pun pecah antarkubu modernis, tradisionalis serta fundamentalis sehingga sulit dicari benang merah antara agama dan politik.

Rahman juga terjun ke dalam arena kontroversi ini dengan menulis Implementation of the Islamic Concept of State in Pakistani Miliieu. Dalam artikel ini, Rahman dengan sepenuhnya mendukung dan mengelaborasi gagasan kenegaraan kalangan modernis serta memberinya basis al-Qur'an dan sunah nabi yang kukuh. Bagi Rahman karena organisasi negara dalam Islam menerima mandat nya dari rakyatyakni masyarakat muslim yang keberadaannya adalah mengimplementasikan kehendak Tuhan sebagaimana yang diwahyukan dalam Alquran dan modalnya diciptakan Nabi dalam sejarah-maka organisasi tersebut tentunya bersifat demokratis. Adapun bentuk demokrasi ini beragam selaras dengan kondisi aktual suatu masyarakat. Rahman merujuk institusi Arab pra-Islam, nadi, yang menurutnya telah didemokratisasi Alquran sebagai syura, dan pemilihan Khalifah Abu Bakar sebagai pijakan bagi teori demokrasi atau teori kedaulatan rakyatnya. Pada titik ini, ia membantai habis-habisan teori kedaulatan Tuhan Maududi. Rahman. Mengemukakan

Pandangan Fazlur Rahman ini dilatarbelakangi oleh realitas-realitas politik di Pakistan, dimana raja sebagai penguasa tertinggi merupakan wakil Tuhan di muka bumi. Raja jauh dari kekeliruan dan kesalahan. Karena itu, kebijakannya dianggap benar dan hendak dapat dirubah oleh siapapun. Menurut Rahman, tujuan utama negara Islam adalah

2 Ihsan Ali Fauzi, "Mempertimbangkan Neo-Modernisme", dalam Islamika: Jurnal Dialog Pemikiran Islam, No.2 Oktober-Desember 1995, hal. 3

${ }^{3}$ Abd A'la, Dari Neomodernisme ke Islam Liberal: Jejak Fazlur Rahman dalam Wacana Islam Indonesia, Jakarta: Yayasan Wakaf Paramadina, 2003, hal. 44. 
memelihara keamanan dan integritas negara, menegakkan hukum dan keterampilan serta membangun negara, sehingga setiap individu mampu merealisasikan seluruh potensi dan menyumbangkannya untuk kesejahteraan umum. Tujuan ini tentunya membutuhkan suatu otoritas sentral yang cakap, yang pada berikutnya terdapat seorang kepala eksekutif. Kepala eksekutif dipilih oleh rakyat menjalankan aspirasi mereka, dan dibantu oleh struktur pemerintahan yang kompeten dan memahami aspirasi rakyat. Di samping itu, kepala negara juga didampingi oleh suatu majelis legislatif (majelis syura ijma) yang mewakili kehendak rakyat. Tugas majelis ini adalah merumuskan hukum berdasarkan konsensus masyarakat. Penekanan tegas terhadap aktivitas legislative lembaga syura ijma' ini membuat Rahman menolak klaim kalangan tradisionalis ataupun fundamentalis bahwa para ulama yang memiliki hak privilese eksklusif merumuskan hukum. Baginya ijtihad bukanlah hak istimewa kalangan manapun, tetapi merupakan hak setiap muslim yang tidak dapat diganggu gugat. ${ }^{4}$

Rahman memberikan perhatian yang serius terhadap teologinya. Baginya warisan pemikiran teologi-teologi terdahulu sejauh menyangkut hal-hal yang positif harus dipertahankan dan sebaliknya terhadap doktrin-doktrin yang kurang lurus dan tidak dapat diketemukan akar-akarnya dalam ajaran Al-Quran perlu direkonstruksi. Pemikiran teologi klasik terlalu asyik terbawa pada doktrin agama yang kemudian dibungkus dengan bahasa yang falsafi. Pada umunya para islam semata-mata memertahankan ajaran-ajaran agama dengan argumen-argumen rasional, dan bukan menyelidiki dan menafsirkannya dengan metode-metode rasional. Akibatnya, muncullah rumusan dan argumen yang sophisticated (rumit) yang diambil dari falsafat yang tidak dapat dijangkau oleh masyarakat umum, sedangkan dogma dan isinya tetap tidak mengalami perubahan; tanpa suatu penafsiran yang substansial (substantial reinterpretation.) Yang lebih parah dalam perkembangannya, konsep-konsep itu banyak terkonsentrasi pada soal-soal ketuhanan dan inilah yang mengakibatkan wacana teologi menjadi sangat bercorak teosentris. ${ }^{5}$

\section{Pemikirannya tentang Epistemologi}

Fazlur Rahman melihat pentingnya rumusan pandangan dunia (worldview) yang menyeluruh dan utuh sebagai landasan filosofis bagi metodologinya. Konsep pandangan dunia Fazlur Rahman, khususnya berkaitan pada tiga persoalan: Tuhan, manusia, dan alam, bertitik tolak dari al- Qur'an. Konsep Tuhan seperti dinyatakan di dalam al-Qur'an bagi Fazlur Rahman pada dasarnya semata-mata fungsional; Tuhan dibutuhkan bukan karena siapa Dia atau bagaimana Dia, tetapi karena apa yang Dia lakukan.

Berangkat dari landasan di atas, kita dapat mengambil gagasan Fazlur Rahman tentang Tuhan yang kemudian mewarnai berbagai pandangannya yang lain. Dengan kata lain, pandangan Fazlur Rahman tentang Tuhan selanjutnya dapat berimplikasi pada bagaimana Fazlur Rahman melihat segala fenomena di alam ini. Dalam pandangannya,

\footnotetext{
${ }^{4}$ Nyanyu Soraya, "System pemerintahan islam Pakistan dalam pandangan Fazlur Rahman", Bengkulu. Jurnal Madania Vol. XVII No. 1. 2013. hal 97

${ }^{5}$ Haerul Anwar, "Teologi islam perspektif Fazlur Rahman", Jurnal UIN JKT Ilmu Ushuluddin, Vol 2 No. 2. 2014 hal. 126
} 
Tuhanlah yang telah menciptakan manusia dan alam raya ini. Tuhan telah menjadikan alam dengan seperangkat aturannya yang dia sebut dengan istilah qadar. Qadar bagi Fazlur Rahman bukanlah seperti apa yang dipahami oleh mayoritas para teolog (mutakallim) sebagai ketentuan yang deterministik, mengikat serta membatasi kebebasan manusia, melainkan segala ketentuan yang ada pada alam ini, terutama benda-benda fisik ${ }^{6}$

Qadar itulah yang memberikan karakteristik dan sifat. Karakteristik dan sifat itulah yang merupakan amar Tuhan terhadap alam, karena alam semesta tunduk dan patuh terhadap amar Tuhan. Amar Tuhan itulah yang kemudian menjadi amanah bagi alam ini. Karenanya, alam bertasbih kepada Tuhan. Tuhan menciptakan alam semesta ini bukanlah tanpa tujuan. Ia hendak merealisasikan tujuan-Nya itu lewat ciptaan-Nya dan misi-Nya. Tujunnya adalah kebaikan. Pada titik ini, bisa dikatakan bahwa Fazlur Rahman percaya, setidaknya menerima, yang disebut dalam terminologi Filsafat Agama sebagai argumen teologis. Argumen ini menyatakan bahwa alam memiliki tujuan. Alam mengarah kepada suatu tujuan yang lebih tinggi, yakni kebaikan. Sudah merupakan anggapan umum bahwa Tuhan dalam Islam adalah transenden secara mutlak, hal ini terbukti dengan adanya penekanan tegas yang diberikan Islam terhadap pengesaan Tuhan, keagungan-Nya, kemuliaan-Nya, dan lain-lain. Akan tetapi, menurut Fazlur Rahman, gambaran semacam ini tidak muncul dari al-Qur'an, melainkan dari perkembangan teologi Islam belakangan. Tentu saja imanensi Tuhan ini sedikitpun tidak berarti perbuatan-perbuatan yang dilakukan oleh alam atau manusia secara nyata dilakukan oleh Tuhan. Tuhan bukanlah saingan atau pengganti bagi manusia atau agen-agen alam dalam menghasilkan efek-efek. Hukum alam adalah bagian dari perilakuNya (sunah).

Fazlur Rahman dalam menuliskan pemikirannya menggunakan metode kritik sejarah, sebelum ia mengembangkan metode penafsiran sistematis, dan kemudian dengan metode gerak-ganda atau yang dikenal sebagai metode double-movement. Metode double movement, merupakan penyempurnaan dari kedua metode sebelumnya. Gerak ganda yang dimaksud adalah gerakan dari situasi sekarang, kembali kemasa Al Quran diturunkan, kemudian kembali lagi kemasa kini. Menurut Rahman, jika umat Islam dewasa ini dapat menerapkan metode double movement dalam pendidikan mereka, niscaya akan melahirkan ilmuwan yang kritis dan kreatif. Gerakan ganda yang dimaksudkan diatas terdiri dari dua langkah, yakni: Pertama, membawa problem-problem sosial saat ini untuk dicarikan solusinya dalam Al-Qur'an, kemudian mengkaji makna ayat dan situasi historis ayat itu diturunkan. Kedua, memaknai ayat Al-Quran dan mengambil tujuan moralsosial yang terdapat dalam ayat tersebut. ${ }^{7}$

\section{Konsep Teologi}

Berdasarkan metodologi yang dikembangkannya, Fazlur rahman mengangkat masalah-masalah teologi dalam bentuk konsep yang holistik dan kontekstual. Ia

\footnotetext{
6 Budi harianto "Tawaran metodologi Fazlur Rahman dalam teologi islam". Jurnal IAIN Tulung Agung Vol. 04 No 02 2016. Hal 284

${ }^{7}$ Hadi Prayitno. "Konsep pemikiran Fazlur Rahman tentang modernisasi pendidikan islam dan relevansinya terhadap pendidikan islam di Indonesia”, Jurnal Al-Fikri Vol 2 No 2 2019. Hal 40
} 
meletakkan bahasan teologisnya dalam perspektif signifikansinya terhadap keberadaan manusia dalam kehidupan di dunia, tanpa harus menafikan kehidupannya diakhirat nanti.

\section{Wujud Tuhan}

Fazlur Rahman dalam menerangkan gagasan tentang Tuhan dan alam semesta senantiasa mengacu pada al-Quran sebagai sumber otoritas primer dan representator Allah yang senantiasa aktual dan kontekstual dalam setiap masa dan keadaan di mana manusia berada. Pijakan dan landasan dasar Rahman adalah alQuran sehingga tidak terlalu berlebihan bila pemiki sering disebut sebagai tokoh Quranik sentris, karena memang seluruh pola pikirnya jika kita amati selalu dimulai dari dan bertujuan kepada maksud alQur'an, maka dari itu kerangka pikir Rahman adalah sangat Qur'anik sekali

Menurut Rahman semua pernyataan al-Quran tentang alam ataupun Tuhan sekalipun, pada dasarnya menyatakan tentang manusia. Hal ini ditunjukkan oleh al-Quran yang dengan tegas menolak untuk menyinggung masalah kekuasaan Ilahi. Dengan mengutip beberapa ayat al-Quran, menurut Rahman, al-Quran hanya menyatakan bahwa Tuhan Mahakuasa dan manusia diberi pilihan dan diserahi tanggung jawab. Salah satu fungsi gagasan tentang Tuhan adalah menjelaskan keteraturan alam semesta sekaligus bahwa konsep Tuhan merupakan bagian dari logika yang inheren yang harus ada, dengan memberi pernyataan bahwa Tuhan bukan saja transenden tetapi juga imanen. Hal ini dibuktikan oleh ayat-ayat al-Quran yang berhubungan dengan seluruh proses dan peristiwa alam kepada Tuhan ${ }^{8}$

Menurut Rahman, Tuhan itu memang dekat, namun bisa juga dipandang sangat jauh. Lebih lanjut katanya bahwa yang menjadi masalah bukanlah bagaimana membuat manusia beriman dengan mengemukakan bukti-bukti teologis yang panjang lebar tentang eksistensi Tuhan, tetapai bagaimana membuatnya beriman dengan mengalihkan perhatiannya kepada berbagai fakta yang jelas dan mengubah fakta-fakta ini menjadi halhal yang mengingatkan manusia kepada eksistensi Tuhan. Tuhan adalah dimensi yang memungkinkan adanya dimensi-dimensi lain. Dia memberikan arti dan kehidupan kepada setiap sesuatu. Dia serba meliputi; secara harfiah dia adalah tak terhingga dan hanya Dia sajalah yang tak terhingga

\section{Wahyu dan Kenabian}

Menurut Rahman, al-Quran sebagai sesuatu yang bersifat ilahi sudah barang tentu dipandang dan diyakini bersifat abadi (Qadīm), suatu pandangan yang sangat ditentang oleh kalangan Mu'tazilah dan menjadi keyakinan dan kesepakatan kalangan Sunni. Dalam hal kenabian, menurutnya para Nabi adalah manusia-manusia biasa yang karena ketabahan mereka, kepekaan mereka karena wahyu Allah yang mereka terima serta yang kemudian mereka sampaikan kepada manusia dengan ulet tanpa mengenal takut dapat mengalihkan hati nurani umat manusia. Tidaklah aneh, janggal atau tercela jika sebagai manusia biasa seorang Nabi tidak selalu konsisten. Justru sebagai manusia biasa

${ }^{8}$ Muhammad Ramadhan, "Pemikiran teologi Fazlur Rahman", Sumatera utara. Jurnal UIN Walisongo

Teologia. Vol. 25. No 2. 2014 hal 5

Al-Hikkmah: Jurnal Studi Agama-Agama/Vol. 7 , No. 2, 2021 
itulah ia menjadi teladan bagi umat manusia. Muhammad tidak pernah ingin menjadi Nabi atau mempersiapkan dirinya menjadi seorang Nabi.

Pengalaman religius Muhammad terjadi secara tak terduga karena pengalaman ini bagaikan orang mati yang hidup kembali. Dalam pengertian yang naturalistis Muhammad memang mempersiapkan dirinya menjadi seorang Nabi (walupun tampa ia sadari) karena sejak kecil ia memiliki kepekaan yang intensif dan natural terhadap moral yang dihadapi oleh manusia dan kepekaannya ini semakin tajam karena ketika masih belia ia sudah menjadi yatim.

Fazlur Rahman menolak secara tegas pandangan mengenai pewahyuan yang mekanis dan eksternal sebagaimana pandangan kalangan otrodoks, sehingga penyampaiannya terkesan seakan-akan Jibril datang dan mengantarkan risalah Tuhan kepada Nabi Muhammad, seperti seorang tukang pos yang menyerahkan surat. Penyampaian semacam inilah yang tidak dapat diterima Fazlur Rahman karena dalam proses semacam itu sulit untuk menghubungkan antara yang transendental dan ilahi pada satu pihak, dan Nabi sebagai manusia pada pihak lain. Menurut Rahman, Jibril bukan tokoh semacam "tukang pos" yang menyampaikan wahyu secara mekanis eksternal. Jibril sebagai penyampai wahyu juga dapat diartikan sebagai spirit (Ruh). Pandangannya itu didasarkan pada al-Quran surat an-Nahal [16]: 102 yang menyebutkan bahwa Ruh alQudus menurunkan al-Quran kepada Nabi. Menurutnya, Ruh suci itu bukan hanya sekedar Malaikat yang berdiri sendiri. Istilah malaikat tidak tepat dikenakan kepada yang menyampaikan wahyu kepada Muhammad itu. Kepada Muhammad al-Quran tidak menyatakan penyampai wahyu itu sebagai malaikat tetapi sebagai ruh atau utusan spiritual. $^{9}$

Menurut Fazlur Rahman para nabi adalah manusia-manusia luar biasa yang karena kepekaan mereka, ketabahan mereka, karena wahyu Allah yang mereka terima serta yang kemudian mereka sampaikan kepada manusia dengan ulet tanpa mengenal takut dapat mengalihkan hati nurani umat manusia dari ketenangan tradisional dan tensi hipomoral kedalam suatu keawasan sehingga mereka dapat menyaksikan Tuhan sebagai Tuhan dan syeitan sebagai syeitan. Dalam Surah al- Baqarah ayat 285, disebutkan bahwa ada empat unsur yang perlu diimani yakni, beriman kepada Allah, malaikat, kitab-kitab, dan Rasul-rasulNya. Sedang hari Akhir, Qadha dan Qadhar tidak dimasukkan ke dalam unsur keimanan.

Rasul-rasul atau nabi-nabi ini mula-mula diutus mereka sendiri, tetapi ajaran yang mereka sampaikan itu tidak terbatas kepada negerinya saja. Ajaran mereka bersifat universal dan harus diyakini serta diikuti oleh semua manusia. Seorang nabi harus berhasil memperoleh dukungan dari kaum nya. Jika tidak demikian, maka sedikit sekali kemungkinan bahwa ajarannya sampai kepada kaum-kaum lainnya dan kalaupun sampai tentu telah mengalami perubahan (distorsi).

Adapun Muhammad dalam pandangan umat Islam, adalah seorang pahlawan utama. Sedang menurut pandangan para pemikir dari agama-agama lain, dia adalah

${ }_{9}^{9}$ Fazlur Rahman. Tema tema pokok. PT mizan pustaka bandung, Hal 88 
seorang pembangun umat terbesar, diakui mutlak. Segi kelaki-lakiannya telah menggerakkan perasaan semua orang sepanjang zaman, baik yang beriman maupun yang kafir. Sekiranya Muhammad, rasul yang mulia ini, tidak dipersiapkan fitrahnya untuk tugas kerasulan yang besar yang harus dia tunaikan, tentu dia takkan menjadi rasul

Utusan-utusan Allah kepada umat manusia oleh al-Qurean dinamakan nabi dan rasul. Tidak seperti di dalam bibel, di dalam al-Quree an Nabi yang menyampaikan Khabar tidak berarti yang menerangkan dimasa mendatang, tetapi yang menyampaikan khabar dari Allah. Nabi diutus Allah untuk mencegah kejahatan dan menyampaikan khabar gembira kepada orang-orang yang shaleh. Itulah sebabnya mengapa istilah-istilah yang menyampaikan kabar gembira dan yang menyampaikan peringatan sering dinyatakan alQurean, terutama sekali dimasa-masa awal kenabian Muhammad. ${ }^{10}$

\section{Kehendak dan Perbuatan Manusia}

Manusia menurut Rahman merupakan mahluk yang memiliki kelebihan dibanding mahluk-mahluk lain. Analisis terhadap kelebihan yang dimiliki manusia merupakan hasil pemahamannya terhadap al-Quran. Berdasarkan ayat 30-33 surat alBaqarah, dan surat al-Ahzab ayat 72 yang berbicara tentang penyerahan amanah11 Allah kepada manusia, Rahman mengungkapkan bahwa ayat-ayat tersebut menunjukkan adanya potensi dan possibilitas tertentu yang hanya dapat direalisasikan manusia, dan tidak dapat dilaksanakan oleh mahluk yang lain. Kongkritnya, hanya umat manusia yang mampu berprestasi dan membangun dunia dan kehidupan. Sedang mahluk Allah yang lain, termasuk malaikat tidak mempunyai kemampuan menjalankan amanat Allah tersebut.

Sebagai implikasi dari tesisnya tentang kebebasan manusia, ia meyakini kesesatan yang dialami manusia disebabkan oleh manusia itu sendiri. Penyesatan itu bukan dilakukan oleh Allah. Sebab alQuran tidak pernah menyatakan bahwa Allah menutup hati dan menyesatkan manusia secara semena-mena. Namun al-Quran menyatakan bahwa Allah berbuat demikian karena tindakan manusia sendiri, atau karena sebab-sebab lain yang banyak disebutkan al-Quran.

Doa menurut Rahman adalah sikap pikir yang aktif dan reseptif, dimana manusia sebagai agen ketika melakukan usaha moral, atau kognitif, ia selalu mencari pertolongan dari Sumber Kehidupan. Dengan demikian, energi-energi baru mengalir kedalam jiwa seseorang yang berdoa tersebut. Namun hal itu tentunya harus disertai dengan perjuangan, atau usaha yang keras dari orang yang berdoa itu. Bagi Rahman, doa memiliki nilai yang sangat positif dalam kehidupan seorang muslim. Melalui doa yang disertakan dalam setiap usaha dan tindakannya yang kongkrit, seorang muslim akan selalu bersikap optimis dalam menghadapi kehidupan yang akan dijalaninya.

Berdasarkan uraian tersebut, adanya kebebasan pada tindakan manusia hanya dapat dipahami sebagai suatu kebebasan terbatas yang muncul karena adanya karunia Allah. Kekuasaan manusia tidak akan pernah melampaui kekuasaan Allah. Karena

${ }^{10}$ Aksin Wijaya, "Mendiskuruskan kembali konsep kenabian". Jurnal Pemikiran Islam At-Tahir. Vol 5. No.2. 2005. Hal 131

${ }^{11}$ Fazlur Rahman, Islam dan Modenitas, Tentang Transpormasi Intelektual, Bandung: Pustaka, 1985, hal. 87 
keterbatasannya itu, manusia harus selalu meminta pertolongan kepada Allah dalam bentuk doa dan usaha yang nyata. Doa membuat manusia optimis dalam setiap usaha dan kerjanya, sedangkan usaha merupakan realisasi dari optimisme yang dimilikinya sehingga sikap itu benarbenar diwujudkan dalam bentuk aktivitas yang kongkrit.

Masih dalam kaitannya dengan kebebasan manusia, Rahman mengungkapkan, meskipun kebebasan itu berasal dari Allah, manusia benar-benar bebas menentukan pilihan dan tindakannya. Sebab qadar dalam perspektif Islam bukan penentuan terhadap kejadian sesuatu, atau terhadap tindakan yang dilakukan manusia. Segala sesuatu yang ditentukan Allah bukan lah kejadian tentang sesuatu, tapi potensinya. Melalui potensi yang telah ditentukan Allah, manusia dapat mengolah sesuatu dan mengembangkannya secara bebas dan kreatif, tanpa terkait dengan adanya predeterminasi yang kaku.

Berdasarkan uraian tersebut, manusia dalam tesis Rahman adalah mahluk yang benar-benar bebas, tetapi kebebasan yang dimilikinya adalah sebagai manifestasi limpahan kasih Allah yang tidak berkeputusan, bukan kebebasan yang muncul dengan sendirinya. Dengan kebebasan itu, manusia mempunyai tugas sebagai khalifah Allah, yaitu amanah untuk memperjuangkan dan menciptakan sebuah tata sosial yang bermoral di muka bumi. Dalam konteks ini ada hubungan yang erat antara kebebasan manusia di satu sisi dan tugas moral yang harus diemban manusia pada sisi yang lain.

Jadi menurut Rahman, inti persoalan yang harus diangkat dalam wacana tentang kebebasan manusia bukan terletak pada hakekat kebebasan atau determinisme itu sendiri, tapi pada upaya menjadikankebebasan itu sebagai pendorong bagi manusia agar selalu hidup diatas prinsip-prinsip moral yang telah digariskan agama. Pada sisi itulah tanggung jawabmerupakan aspek yang tidak dapat diabaikan. Dalam ungkapan yang lain, kebebasan harus ditempatkan diatas kerangka tanggung jawab. Konsep kebebasan manusia yang dilepaskan dari tanggung jawab hanyan akan melahirkan dampak negatif bagi kehidupan dan bertentangan secara diametral dengan tujuan kebebasan itu sendiri. Sebab tanpa adanya sutau tanggung jawab, tindakan manusia hanya akan melahirkaan kesewenang-wenangan, kelaliman, pengrusakan dan bentuk-bentuk tindakan negatif atau destruktif yang lain.

Sebagai konsekuensi lebih jauh dari pemahamannya tentang tanggung jawab individu itu, Rahman lalu menolak konsep syafaat (juru selamat) dalam Islam. Berdasarkan surat al-Baqarah ayat 233 dan 286 mengenai pertanggungjawaban seseorang sesuai dengan kemampuannya, serta ayat 254 surat yang sama tentang kesia-siaan persahabatan dan tolong-menolong manusia pada hari perhitungan, ia berargumentasi bahwa al-Quranmenolak penengah antara manusia dengan Allah. Penolakannya terhadap konsep syafaat karena hal ini bertentangan dengan sikap dasar Islam yang sangat memperhatikan usaha, perjuangan, dan tanggung jawab individu.

Dengan tesisnya yang menegasikan syafaat, dia menafsirkan ayat-ayat semacam surat al-Baqarah ayat 255 yang menyebutkan mengenai kemungkinan pemberian syafaat oleh seseorang yang mendapat izin Allah sebagai pernyataan yang bersifat alegoris untuk menggambarkan keagungan Allah yang dihadapannya tidak ada satu manusiapun yang berdaya kecuali dengan rahmat-Nya. Menurutnya ayat tersebut 
tidak dapat ditafsirkan secara literal sebagai adanya syafaat dari seseorang kepada yang lain. Penolakannya terhadap konsep syafaat itu merupakan upaya untuk menekankan signifikansi penggunaan kemampuan dan kebebasan yang diperoleh manusia agar ditujukan kepada kebaikan. Sebab bila kemapuan dan kebebasan itu dipergunakan untuk hal-hal yang jahat, maka yang akan menanggung akibatnya adalah si pelaku sendiri. Dalam kondisi ini, tidak ada seorangpun yang dapat mengangkatnya dari lembah itu kecuali atas usahanya sendiri, dan atas rahmat Allah. Oleh karena itu ia menyangkal adanya syafaat yang telah menjadi keyakinan kebanyakan tokoh-tokoh Islam karena hal itu mengurangi aspek tanggung jawab yang menjadi salah satu titik penekanan dalam konsep teologisnya, sebagaimana juga akan mengurangi dorongan kepada seseorang untuk melakukan usaha dan perjuangan yang bersifat individual.

Paparan tersebut menyimpulkan bahwa tesis kebebasan manusia yang ditawarkan Rahman, merupakan proses pengembaraan intelektual-keagamaannya dalam rangka mengkritisi, meluruskan dan atau menyempurnakan tesis-tesis aliran yang dianggapnya terperangkap dalam pandangan yang ekstrem. Berdasarkan metode yang berorientasi kepada al-Quran, ia menawarkan suatu solusi terhadap kelemahan tesis mu'tazilah mengenai kebebasan manusia yang terlalu rasionalistik. Dengan pola semacam itu, Rahman melalui konsepnya mampu menghadirkan sosok manusia yang sesuai dengan fitrahnya, manusia religius yang sangat tergantung kepada kekuasaan Tuhan, tapi tetap benar-benar memiliki kebebasan, bukan kebebasan semu sebagaimana paham Asy'ariyah dan aliran-aliran lain yang satu ide dengan Asy'ariyah. Namun kekuatan idenya menjadi bias ketika ia menolak konsep syafaat. Argumentasi Rahman bahwa syafaat akan mengurangi tanggung jawab individu kurang memiliki alasan dan dasar yang kokoh, serta ia terkesan terperangkap pada pemahaman al-Quran secara parsial. Selama konsep syafaat dipahami pada posisi yang benar, misalnya hal itu hanya berlaku bagi orang yang bertaubat, maka konsep itu tidak akan mereduksi usaha dan tanggung jawab seseorang. Bahkan dengan pengakuan terhadap keberadaan konsep itu, seorang yang beriman semakin berusaha untuk memperolehnya melalui amal saleh. ${ }^{12}$

\section{Eskatologi}

Rahman memandang kehidupan akhirat merupakan suatu kejadian konkrit; kejadian yang pasti terjadi. Ia menegaskan bahwa di akhirat nanti manusia akan menerima pengadilan dari Allah. Adanya pengadilan pada hari itu tidak dapat dipisahkan dari tindakan Allah yang lain. Pengadilan merupakan suatu rangkaian dari penciptaan, pemeliharaan, dan pemberian petunjuknya yang semuanya merupakanmanifestasi dari kepengasihan Allah SWT. Bagi Rahman, konsep tentang Akhirat harus dipahami secara holistic, Artinya, kebenaran Akhirattidak dapat dilepaskan dari kepengasihan Allah. Ia dengan rahmat kasihnya tidak akan membiarkan manusia dalam ketidakdewasaan moralnya. Tanpa adanya balasan dan pengadilan, manusia tidak akan pernah dewasa secara moral, sebab ia akan hidup tanpa merasa takut lagi untuk melakukan apa saja yang dikehendakinya tanpa memikirkan tanggungjawabnya sebagai makhluk moral. Karena itu,

${ }^{12}$ Muhammad Ramadhan, "Pemikiran teologi Fazlur Rahman”. Jurnal UIN Walisongo Teologia. Vol. 25. No 2. Hal 11

Al-Hikkmah: Jurnal Studi Agama-Agama/Vol. 7 , No. 2, 2021 
Allah meletakkan akhirat dalam kerangka nilai-nilai moral untuk proses pendewasaan manusia.

Bagi Rahman konsep tentang Akhirat tidak terlepas dari konteks kehidupan aktual manusia, karena hal itu akan berimplikasi pada terciptanya suatu kehidupan yang lebih baik dan lebih bermoral, dan hal itu pula yang sebenarnya menjadi tujuan diturunkannya agama ke dunia ini.

Kematian merupakan proses niscaya yang mutlak yang akan dihadapi oleh manusia. Siapa pun yang bernyawa pasti akan mati. Keniscayaan ini di satu sisi dapat menjadi cambuk untuk meraih Taqwa, namun di sisi lain membuat orang menikmati kehidupan dunia sepuasnya dengan keyakinan bahwa inilah kehidupan sejati. Setelah kehidupan ini, tidak ada lagi kehidupan, tidak ada pembalasan Seperti yang diyakini oleh orang-orang Makkah Jahiliyyah saat Al-Quran diturunkan. ${ }^{13}$

\section{Setan dan Kejahatan}

Fazlur Rahman menjelaskan dalam buku Islam dan Modernitas (1985) bahwa sebagai suatu sosok, setan pada awalnya berasal dari semacam bangsa jin. Fazlur Rahman membedakan antara jin pada satu sisi dengan setan atau iblis pada sisi yang lain. Untuk menjelaskan perbedaan itu, ia mengutip beberapa ayat al-Qur'an. Salah satu ayat yang ia kutip adalah surat Saba': 12 tentang adanya jin-jin yang mengabdi kepada Sulaiman, dan surat alAn'am [6]: 130 mengenai pernyataan Allah Swt. bahwa Ia telah mengutus para Rasul kepada manusia dan jin, serta surat-surat lain yang sejenis.dari ayat-ayat tersebut, Fazlur Rahman menyimpulkan bahwa pada dasarnya jin adalah mahluk yang tidak berbeda dengan manusia kecuali mereka lebih besar kecenderungan kepada kejahatan dan kebodohan. Para jin juga mempunyai tabiat yang panas dan kekuatan yang sangat besar. Selain itu, jin juga tidak seperti manusia. Jin adalah makhluk yang termasuk ke dalam golongan mahluk ghaib yang berasal dari esensi api.

Pengungkapan tersebut menunjukkan bahwa Fazlur Rahman menyatakan jin adalah mahluk yang benar-benar bersifat person, bukan sekedar metafora atau simbol semata. Sedangkan setan bisa diartikan dengan dua pengertian. Pertama, sebagai suatu person. Kedua, sebagai kiasan. Analisis di atas berlaku untuk setan dalam peristiwa turunnya Adam dan Hawa.Dalam kisah Adam dan Hawa, iblis adalah person yang bukan hanya mengingkari perintah Allah Swt. dengan menolak menghormat kepada Adam, tapi juga terlibat perdebatan dengan Allah Swt. lantas bersumpah untuk menggoda manusia. Tatkala Adam dan Hawa telah tergoda dengan memakan buah terlarang, maka yang menggoda mereka bukan lagi iblis, tapi setan yang menjadi sebutan bagi prinsip kejahatan. Setan muncul sebagai manifestasi keburukan dan kejahatan yang bersifat objektif, bukan lagi sebagai person tertentu.

Fazlur Rahman menegaskan bahwa kongkritnya, setan bukan suatu prinsip antiTuhan. Setan adalah satu kekuatan anti-manusia yang tiada henti berupaya untuk menyimpangkan manusia dari kebenaran. Setan tidak akan berhenti sampai manusia terperosok ke dalam jalan yang sesat. Dari landasan berpikir di atas, Fazlur Rahman

${ }^{13}$ Haerul Anwar, “Teologi islam perspektif Fazlur Rahman”, Jurnal UIN JKT Ilmu Ushuluddin, Vol 2 No. 2. 2014 hal. 139

Al-Hikkmah: Jurnal Studi Agama-Agama/Vol. 7 , No. 2, 2021 
menekankan bahwa ide terpenting yang bisa kita petik dari al-Quran adalah bahwa aktivitas setan memasuki setiap bidang kehidupan manusia dan manusia harus selalu berjaga-jaga. Jika manusia mengendorkan kewaspadaannya, maka ia mudah terbujuk oleh godaan setan.

Kepada Nabi Muhammad dikatakan:"Apabila setan menggoda berlindunglah kepada Allah Swt., sesungguhnya Allah Swt. mendengar dan mengetahui." (QS. al-A'rāf [7]: 200201).Menurut Fazlur Rahman, sebenarnya cengkeraman setan itu tidak kuat. Cengkeraman tersebut hanya dipengaruhi kelemahan, tidak adanya keberanian moral, dan tidak adanya kewaspadaan di dalam diri manusia yang membuat setan terlihat menjadi semakin kuat.

Ia juga menekankan bahwa iblis atau setan sebenarnya tidak kuat, tapi licik dan licin. Setan lebih banyak mempergunakan tipudaya dan siasat daripada menantang dengan terangterangan. Aktivitas setan tidak menggempur, tapi membujuk, atau berkhianat dan menghadang. Jadi, kekuatan setan sangat bergantung pada kelemahan manusia. Maka dari itu, perjuangan moral sangat penting bagi manusia dalam kehidupannya. Kebebasan yang dimiliki manusia tidak akan bernilai jika tidak benar-benar diarahkan pada kebaikan. ${ }^{14}$

\section{Penutup}

Fazlur Rahman mencoba menawarkan beberapa hasil analisisnya terhadap fenomena-fenomena yang menjadi penyebab pendidikan Islam tidak berkembang, bahkan mengalami kemunduran, diantaranya: pertama, bahwa pendidikan Islam tidak hanya berorientasi pada kehidupan akhirat, tetapi juga harus beorientasi pada kehidupan dunia dengan di landasi dari dasar-dasar Al-Quree an dan AlHadits. Kedua, harus adanya integrasi antara ilmu pengetahuan Islam dan ilmu pengetahuan Sekuler (modern). Dikotomi dan dualisme dalam dunia pendidikan harus dihilangkan. Ketiga, Pendidikan Islam yang dilakukan hendaknya dapat membentuk peserta didik yang cakap dalam berbahasa, kritis, kreatif, dan bermoral yang berlandaskan pada Al-Qur'an dan Al-Hadits serta memiliki intelektual yang berkualitas. Keempat, mengganti metode lama (hafalan) dengan metode memahami dan menganlisis. serta menjadikan kognitif, afektif dan psikomotorik sebagai bagian kurikulum dalam pendidikan.

Dari beberapa pemikiran Fazlur Rahman maka dapat ditarik kesimpulan secara garis besar: Fazlur Rahman adalah termasuk salah seorang tokoh pemikir Isalam kontemporer yang berasal dari pakistan yang oleh para pengamatpemikiran dikelompokkan sebagai pemikir neomodernis, fazlurrahaman juga amat kritis dalam melihat pemikiran Islam yang lepas dari konteks "Normativitas" dan "Historisirtas"nya. Ia juga berpandangan bahwa pengembangan pemikiran Islam harus selalu berakar dari pemikiran Islam klasik. Menurut Fazlur Rahman, kendatipun tidak menyatakan secara gamblang pendapatnya mengenai konsep Islam mengenai Negara (pemerintahan), nampaknya lebih cendrung berpendapat bahwa Islam tidak mengajarkan secara jelas mengenai system kenegaraan tetapi mengakui bahwa terdapatnya sejumlah tata nilai dan etika dalam al-Qur'an. Fazlurrahamn juga mempunyai perhatian yang besar terhadap masa depan pendidikan Islam dan bahkan ia menawarkan suatu pandangan bahwa oreientasi

\footnotetext{
${ }^{14}$ https://bincangsyariah.com/khazanah/sebenarnya-cengkeraman-setan-tidak-kuat/
} 
pendidikan sangat perlu diwarnai dengan nilai-nilai Islam sehingga para pelajar muslim dan pengetahuan yang dihasilkan tidak menjadi sekuler.

Rahman mengatakan bahwa semangat dasar adalah moral dan kesan yang paling intens yang ditinggalkan al-Qur'an bagi pembacanya bukanlah berupa Tuhan yang selalu mengawasi, merenggut dan menghukum, sebagaimana dibuat orang-orang Kristen, bukan pula gambaran seorang hakim utama sebagaimana ulama-ulama Fiqh Islam cendrung memikirkannya, tetapi adalah suatu kehendak yang bertujuan dan terpadu yang menciptakan tata tertib dialam semesta, sifat-sifat kekuasaan atau keagungan, kewaspadaan atau keadilan serta kebijaksanaaan yang diatributkan Tuhan di dalam alQur'an dengan penekanan yang jelas, pada kenyataannya adalah kesimpulan-kesimpulan yang paling tepat, dapat diambil dari keteruturan kosmos yang kreatif. Rahman menjelaskan al-Qur'an muncul sebagai suatu dokumen yang dari awal hingga akhir memberikan semua tekanan-tekanan moral, yang perlu bagi tindakan-tindakan manusia yang kreatif dan sungguh kata Rahman kepentingan sentral al-Qur'an adalah pada manusia dan perbaikannya. ${ }^{15}$

\section{Daftar pustaka}

Prayitno, Hadi, 2019, konsep pemikiran Fazlur Rahman tentang modernisasi pendidikan islam dan relevansinya terhadap pendidikan islam di Indonesia, Jurnal Al Fikri, Vol 2 No 2

Ali fauzi, ihsan, 1995"Mempertimbangkan Neo-Modernisme", dalam Islamika, jurnal dialog pemikiran islam, no 2 (hal 3).

A'la, Abd, 2003 “Dari Neomodernisme ke Islam Liberal: Jejak Fazlur Rahman dalam Wacana Islam” Indonesia, Jakarta: Yayasan Wakaf Paramadina

Soraya, Nyanyu. 2013 "System pemerintahan islam Pakistan dalam pandangan Fazlur Rahman” Jurnal Madania Vol. XVII No. 1. 2013. (Hal 97)

Ramadhan, Muhammad.2014 Pemikiran teologi Fazlur Rahman. Jurnal UIN Walisongo Teologia. Vol. 25. No 2.

Wijaya, Aksin Mendiskuruskan kembali konsep kenabian. Jurnal pemikiran islam At-Tahir. Vol 5. No.2. 2005.

Rahman, Fazlur,1985 Islam dan Modenitas, Tentang Transpormasi Intelektual, Bandung: Pustaka

Anwar, Haerul.2014 "Teologi islam perspektif Fazlur Rahman" Jurnal UIN JKT Ilmu Ushuluddin, Vol 2 No. 2.

15 Ajahari, "pemikiran Fazlur Rahman dan Muhammad Arkoun”, Jurnal studi Agama dan Masyarakat IAIN

Palangkaraya Vol 12 no 2 2016. Hal 246

Al-Hikkmah: Jurnal Studi Agama-Agama/Vol. 7 , No. 2, 2021 
Rahman, fazlur, tema tema pokok, Bandung PT Mizan pustaka

https://bincangsyariah.com/khazanah/sebenarnya-cengkeraman-setan-tidak-kuat/

Ajahari. pemikiran Fazlur Rahman dan Muhammad Arkoun. Jurnal studi Agama dan Masyarakat IAIN Palangkaraya Vol 12 no 2. 